\title{
Inotropes in Chronic Beta-Blocker Therapy
}

\author{
Mochamad Yusuf Alsagaff',*, Melly Susanti ${ }^{1}$, Mochammad Thaha ${ }^{2}$, Christian Jonatan ${ }^{2}$
}

Mochamad Yusuf Alsagaff $1, *$ Melly Susanti', Mochammad Thaha ${ }^{2}$, Christian Jonatan ${ }^{2}$

'Department of Cardiology and Vascular Medicine, Faculty of Medicine, Universitas Airlangga, Prof Moestopo Street 6-8, Surabaya, INDONESIA.

${ }^{2}$ Department of Internal Medicine, Faculty of Medicine, Universitas Airlangga, Prof Moestopo Street 6-8, Surabaya, INDONESIA.

\section{Correspondence}

\section{Mochamad Yusuf Alsagaff}

Department of Cardiology and Vascular Medicine, Faculty of Medicine, Universitas Airlangga, Prof Moestopo Street 6-8,

Surabaya, INDONESIA

E-mail: yusuf_505@fk.unair.ac.id

History

- Submission Date: 17-01-2021;

- Review completed: 15-03-2021

- Accepted Date: 31-03-2021.

DOI : 10.5530/pj.2021.13.105

Article Available online

http://www.phcogj.com/v13/i3

Copyright

(C) 2021 Phcogj.Com. This is an openaccess article distributed under the term of the Creative Commons Attribution 4.0 International license.

\begin{abstract}
The increasing rate of cardiovascular disorders contributes to rising hospitalized patients receive chronic oral beta-blocker therapy. Beta-blockers remain one of the fundamental therapy for chronic heart failure. Still, their role in decompensated heart failure and severe sepsis during hospitalization is often debated and inconsistent in clinical practice. In recent years, evidence of the efficacy and clinical outcomes of beta-blockers in acute heart failure (AHF) have accumulated. Clinical research indicates that chronic beta-blockade withdrawals should be prevented, or as soon as hemodynamic stabilization and euvolemic condition are reached, it should be reinstituted. As a subset of AHF patients with low cardiac output required inotropes, the choice of proper agent is fundamental. Different inotropic agents such as inhibitors of the phosphodiesterase, levosimendan, and dobutamine also their associations with beta-blockers are discussed.
\end{abstract}

Key words: Inotropes, Beta-blocker, Decompensated heart failure, Severe sepsis.

\section{INTRODUCTION}

Beta-blockers (BB), across all heart failure spectrums (HF), play a critical role in decreasing the mortality rate and improving functional class. ${ }^{1,2}$ On the contrary to chronic heart failure (HF), data on the tolerance to beta-blockers are minimal in patients that are highly symptomatic due to decompensation or acute HF in hospitalization. The therapeutic dilemma after an HF exacerbation is the issue of reducing or halting long-term betablocker treatment with negative inotropic activity. ${ }^{3-5}$ Co-administering inotropes and beta-blockers will attenuate the desirable hemodynamic effects on the inotropic agent. ${ }^{6}$

Prolonged elevated levels of catecholamines correlate well with a poor prognosis. By the fact that beta-blocker in chronic heart failure have a definite survival benefit, one might assume that beta-adrenergic activation also leads to detrimental long-term effects. ${ }^{7}$ Though many patients treated with beta-blocking agents improved, a small percentage of patients may exacerbate or deteriorate and require hospitalization after the initiation. Therefore, in advanced HF patients and patients who have already received beta-blocker maintenance therapy who do not tolerate betablocker initiation, concomitant treatment of the inotropic and beta-blocker agent may be required.

Increasing long-term mortality has always been a problem considering the inotropic agent, despite the short-term improvement in hemodynamic and symptoms. Indeed, according to the latest published heart failure guidelines from the European Society of Cardiology, inotrope should be reserved for patients with a severe reduction in cardiac output resulting in impaired vital organ perfusion, which occurs most often in hypotensive AHF (Class IIb recommendation, level of evidence $\mathrm{C}) .^{10}$ If beta- blockade is presumed to contribute to hypotension upon hypoperfusion, levosimendan or a PDE III inhibitor may be considered to counter the effects of beta-blockade (Class IIb recommendation, level of evidence C).$^{10}$ The dosage and the corresponding recommendation class and level of evidence of each inotrope in acute heart failure are also outlined in Table 1.

\section{Dobutamine in patients treated with beta-blockers}

Dobutamine has the capability to stimulate beta-1, beta-2, and alpha- 1 receptors, enhancing myocardial contractility, and therefore cardiac output with a slight reduction in systemic vascular resistance. ${ }^{11}$ Thus, the inotropic effects of dobutamine are based on the extent of occupancy of the beta-adrenergic receptors and its signal transduction pathway. ${ }^{12}$ High doses of beta-blockers will counteract the dobutamine pharmacologic actions. The inhibition and simultaneous stimulation of the same receptors $(\beta 1, \beta 2$, and $\alpha)$ appear logical to be inefficient. Nevertheless, the selectivity of the beta-blocker may play a major role in determining the dobutamine response to the beta-blocker. Dobutamine was evidently unable to improve cardiac index and heart rate when combined with non-selective beta-adrenoreceptor blockers (carvedilol) and only to a limited extent with $\beta-1$ selective blockers (metoprolol). ${ }^{13,14}$ This observation may be explained by the fact that (1) metoprolol has a 75-fold selectivity for $\beta 1$ over $\beta 2$ receptor ${ }^{15}$, while the affinity of dobutamine is considerably high for $\beta 2$ receptor $^{16,17}$, which have significant inotropic and chronotropic activity and are left unoccupied, (2) long term therapy with metoprolol may induce upregulation of the $\beta 1$ adrenoreceptor, which in turn may preserve or even enhance dobutamine response ${ }^{15,18}$, where carvedilol does not. ${ }^{8,19}$ Inotropic drugs with different cellular pathways clearly might serve as an alternative in this situation. 
Table 1: Positive inotropes in acute heart failure with recommendation classes and levels of evidence.

\begin{tabular}{|c|c|c|c|c|}
\hline Inotrope & Intravenous bolus dose & $\begin{array}{c}\text { Intravenous maintenance } \\
\text { dose }\end{array}$ & Recommendation class & Level of evidence \\
\hline Dobutamine & No & $2-20 \mu \mathrm{g} / \mathrm{kg} / \mathrm{min}$ & IIb & $\mathrm{C}$ \\
\hline Dopamine & No & $\begin{array}{c}3-5 \mu \mathrm{g} / \mathrm{kg} / \mathrm{min} \text {; inotropic } \\
\text { (inotropic effect) } \\
>5 \mu \mathrm{g} / \mathrm{kg} / \mathrm{min}: \text { inotropic and } \\
\text { vasoconstriction effect }\end{array}$ & IIb & $\mathrm{C}$ \\
\hline Milrinone & $\begin{array}{c}25-75 \mu \mathrm{g} / \mathrm{kg} \\
\text { over } 10-20 \mathrm{~min}\end{array}$ & $0.375-0.75 \mu \mathrm{g} / \mathrm{kg} / \mathrm{min}$ & $\mathrm{IIb}$ & $\mathrm{C}$ \\
\hline Enoximone & $\begin{array}{l}0.5-1.0 \mathrm{mg} / \mathrm{kg} \\
\text { over } 5-10 \mathrm{~min}\end{array}$ & $5-20 \mu \mathrm{g} / \mathrm{kg} / \mathrm{min}$ & IIb & $\mathrm{C}$ \\
\hline Levosimendan & 6 to $12 \mu \mathrm{g} / \mathrm{kg}$ over $10 \mathrm{~min}$ & 0.05 to $0.2 \mu \mathrm{g} / \mathrm{kg} / \mathrm{minute}$ & IIb & $\mathrm{C}$ \\
\hline
\end{tabular}

(modified from Ponikowski et al..$^{10}$ )

\section{When is it safe to initiate beta-blocker in those patients with beta-adrenergic inotropic agents?}

There is a lack of evidence regarding this issue. Based on its duration of action that is generally short ( $\mathrm{T} 1 / 2=2$ minutes), dobutamine is rapidly metabolized by catechol-0-methyltransferase. ${ }^{20}$ It could be safely assumed to initiate a beta-blocker soon after successful weaning of dobutamine.

The importance of initiating beta-blocker on predischarge hospitalized HF patients was evaluated in the IMPACT-HF trial, where predischarge initiation of carvedilol was associated with better compliance of betablocker until 60 days after hospitalization $(91 \%$ vs. $73 \%, \mathrm{P}<0.0001)$ without increasing side effects or duration of hospital stay. Thus, betablockers should be initiated once hemodynamic stability and euvolemic state are obtained, ideally before the patient leaves the hospital. ${ }^{16,17}$

\section{Phosphodiesterase III inhibitors in patients treated with beta-blockers}

Milrinone and enoximone have important differences from dobutamine. The type III PDE inhibitors worked downstream to the $\beta$ - 1 by blocking the breakdown of cyclic adenosine monophosphate in the myocardium and vascular smooth muscle, leading to increased intracellular calcium, producing positive inotropic and lusitropic effects. ${ }^{8}$ The rationale behind the combination of PDE III inhibitors with beta-blocker is that, owing to their site of action that beyond the beta-adrenergic receptor, PDE III inhibitors could maintain their hemodynamic effects in the presence of beta-blockade. $^{21}$

A study by Lowes et al. ${ }^{22}$ evaluated the efficacy of milrinone and dobutamine in patients chronic carvedilol-treated patients. Milrinone administration during concomitant carvedilol therapy significantly increased cardiac index and decreased mean pulmonary artery pressure (mPAP), pulmonary capillary wedge pressure (PCWP), and mean arterial blood pressure (MAP) without altering heart rate. In contrast, dobutamine only improved cardiac index at high doses, which is not usually used for heart failure treatment $(15-20 \mu / \mathrm{kg} / \mathrm{min})$. At these doses, dobutamine also increased heart rate, MAP, and mPAP. These data are in accordance with a study by Metra et al. ${ }^{14}$, which compared the hemodynamic effects of dobutamine and enoximone before and after long-term administration of metoprolol or carvedilol in chronic HF patients. As previously mentioned, carvedilol, and to lesser extent metoprolol, significantly inhibited the desirable hemodynamic effect of dobutamine. At the same time, in the face of beta-blockade, enoximone could maintain or even enhanced its hemodynamic effects. Besides, beta-blockers can minimize the negative effects of PDE III inhibitors by reducing the heart rate along with their pro-arrhythmic effects. ${ }^{23}$ This evidence generally supports the combination of PDE III inhibitors with a beta-blocker, especially carvedilol, when inotropes therapy is necessary. The recommendation from the 2016 ESC HF guidelines supports the use of PDE III inhibitors to reverse the effect of betablockade if beta-blockade is thought to be contributing to hypotension with subsequent hypoperfusion (Class IIb recommendation, level of evidence C). ${ }^{10}$ An important drawback from milrinone would be from the Outcomes of Prospective Trial of Intravenous Milrinone for Exacerbations of Chronic Heart Failure (OPTIME-CHF) trial ${ }^{24}$, with an ischemic etiology, milrinone showed a trend towards higher rates of adverse clinical outcomes.

\section{Levosimendan in patients treated with beta-blockers}

In acute decompensated HF states, levosimendan is increasingly used as a short term treatment when inotropic support is required. It enhances myocardial contractility by binding to troponin C, increasing the sensitivity to calcium, thus depending on intracellular calcium concentrations. ${ }^{25}$ By opening the ATP-sensitive potassium channels, levosimendan exerts its vasodilation effect ${ }^{26}$, and at higher doses, it also inhibits cardiac PDE, predominately PDE III. ${ }^{27}$ Levosimendan acts beyond the beta-adrenergic receptor and thus preserve its hemodynamic effects in concomitant with beta-blocker use. This distinction also contributes to the 2016 ESC HF guidance that levosimendan is the preferred agent for HF patients pretreated with beta-blocker when an inotropic agent is needed (Class IIb recommendation, level of evidence C).${ }^{10}$ Combining treatment with beta-blocker and levosimendan is also potentially favorable.

The hemodynamic effects of levosimendan were compared with dobutamine in low output $\mathrm{HF}$ in Levosimendan Infusion versus Dobutamine (LIDO) trial. ${ }^{28}$ In the sub-group analysis, the concomitant administration of beta-blockers with levosimendan had significant effects on the increase in cardiac output and the decrease in PCWP ( $p=0.01$ and $p=0.03$, respectively). In contrast, the effect of dobutamine on cardiac output and PCWP was mitigated by beta-blockade. The hemodynamic superiority of levosimendan over dobutamine appears to have been enhanced in the face of beta-blockade (Figure 1) ${ }^{28}$

Subgroup analysis of the SURVIVE trial ${ }^{29}$ produced interesting insights. Randomization with levosimendan in patients treated with concomitant beta-blocker treatment has been linked to markedly lower mortality at day 5 than dobutamine arm ( 1.5 vs. $5.1 \%$ deaths; HR, 0.29 ; CI $0.11-0.78, \mathrm{P}=0.01)$. It should be noted that only half of the patients in the SURVIVE trial received beta-blocker, quite a smaller number than current randomized clinical trials, with much higher usage of betablocker. Therefore, it is likely now that the clinical scenario favoring levosimendan use is more popular than at the time of SURVIVE.

In patients with acute decompensated heart failure, Bergh et al. ${ }^{30}$ compare the effects of a $24-\mathrm{h}$ intravenous infusion of levosimendan and 


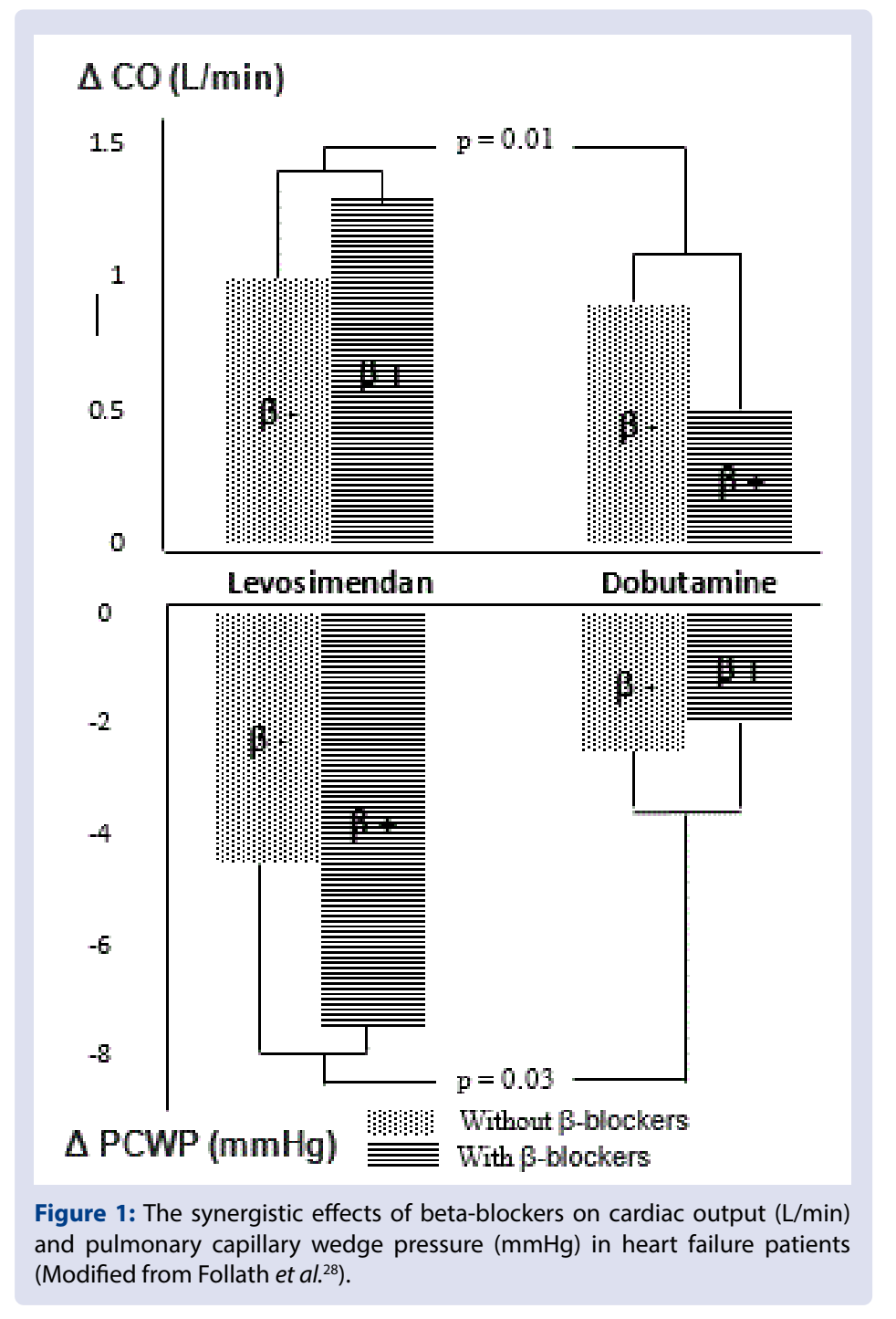

a 48-h infusion of dobutamine. The optimal oral treatment, including a beta-blocker for all patients, was given. The cardiac index was improved by both agents, and PCWP decreased. Similar hemodynamic progress was seen over 24-h, while hemodynamic improvement (increased cardiac index and PCWP decrease) and neuro-hormonal improvement (decline in BNP levels) were substantially greater with levosimendan at 48 hours than with dobutamine.

\section{Beta-blocker in severe sepsis and septic shock, which inotropes to use?}

Sepsis-induced myocardial depression is related to high sympathetic tone. ${ }^{31}$ Septic patients often remain tachycardia even though common factors such as hypovolemia, anemia, agitation, and medication effects are eliminated. ${ }^{32}$ The latest and growing evidence suggests that treatment with beta-blockers will improve cardiovascular parameters and, possibly, the survival rate of severe sepsis or septic shock. ${ }^{33,34}$ Betablockade will limit sympathetic over-stimulation and its related adverse events. $^{32}$

In septic shock patients who were given oral metoprolol to maintained heart rates of less than 95 beats/min, a good safety profile was documented. Morelli et al. investigated the effect of continuous infusion of short-acting $\beta$-blocker, esmolol in 154 septic shock patients. In this randomized controlled study, esmolol that was titrated to maintain heart rate between $80 / \mathrm{min}$ to $94 / \mathrm{min}$ was correlated with a reduction in norepinephrine and fluid requirements and a decrease in mortality (28day mortality of $80.5 \%$ in the control group vs. $49.4 \%$ in the esmolol group) ${ }^{35}$ Furthermore, in a study conducted in 2017 by Fuch et al., from a total of 296 patients with severe sepsis on chronic therapy of betablocker, the continuation of beta-blocker was significantly associated with a decreased rate of hospitalization, 28-day $(P=0.04)$ and 90 -day mortality rates. ${ }^{36}$

Cardiac depression is reported in up to $60 \%$ of septic shock patients, which manifest as global left ventricular hypokinesia ${ }^{37}$, which is the major reason for inotropes use during septic shock. Candidates for vasopressor or inotropes to preserve hemodynamic parameters are patients that may not respond to intensive fluid resuscitation. When it is desired to give beta-blocker to such patients, it is important to choose the right inotropes.

The latest Surviving Sepsis Campaign recommendations support the use of dobutamine, up to $20 \mu \mathrm{g} / \mathrm{kg} / \mathrm{min}$, as a first choice agent in patients with (a) myocardial dysfunction, as suggested by increased cardiac filling pressures and low cardiac output, (b) persistent hypoperfusion in the presence of (b) adequate intravascular volume and adequate MAP using vasopressor agents. Inotropes dose should be titrated based on perfusion as an endpoint. ${ }^{37}$ However, these guideline suggestions are based on a scarcity of evidence on outcomes from randomized controlled trials. 
The preference of dobutamine is based mainly on the early goal-directed therapy randomized controlled trial, in which dobutamine was received in only 14 percent of patients. ${ }^{37}$

The utmost importance to notice about dobutamine in septic patients receiving beta-blocker is the dependency of dobutamine on betaadrenergic receptor occupancy. Although few trials have been conducted, alternative inotropic agents may be used to increase cardiac output in specific scenarios, especially when beta-blocker therapy will be instituted. Every PDE-3 inhibitor has vasodilatory consequences, which may intensify sepsis hypotension, which would theoretically cause harm to its usage throughout this scenario.

Since calcium desensitization plays a significant role in the pathophysiology of septic myocardial depression ${ }^{38}$, the use of levosimendan has also been suggested in septic shock. The latest data regarding levosimendan use in these patients have been promising. ${ }^{39,40}$ It has been documented that levosimendan could reduce serum lactate levels, offer a reno-protective effect, and restores the cardiac index without increasing demand for myocardial oxygen, contributing to better short-term outcomes. ${ }^{40,41}$

\section{CONCLUSION}

In this review, we presented a context for inotropes prescription on patients with chronic beta-blocker therapy, including a summary of possible risks and benefits in the light of more contemporary evidence. Beta-blocker initiation should be pursued once hemodynamic stabilization is established, optimally, before leaving the hospital. Data indicates that persistent beta-blockade elimination during hospitalization should be avoided if possible. The PDE inhibitor or levosimendan that does not interfere specifically with beta-adrenergic receptors can preferably be used for those undergoing beta-blockers and require inotropic therapy.

\section{REFERENCES}

1. Hjalmarson $\AA$, Goldstein $S$, Fagerberg $B$, Wedel $H$, Waagstein $F$ Kjekshus $\mathrm{J}$, et al. Effects of controlled-release metoprolol on total mortality, hospitalizations, and well-being in patients with heart failure: The metoprolol $\mathrm{CR} / \mathrm{XL}$ randomized intervention trial in congestive heart failure (MERIT-HF). Journal of the American Medical Association [Internet]. 2000 Mar 8 [cited 2020 Dec 28];283(10):1295302. Available from: https://pubmed.ncbi.nlm.nih.gov/10714728/

2. Ziff, O.J., Samra, M., Howard, J.P. et al. Beta-blocker efficacy across different cardiovascular indications: an umbrella review and meta-analytic assessment. BMC Med 18, 103 (2020). https://doi. org/10.1186/s12916-020-01564-3

3. Meuwese CL, Kirkels JH, de Jonge N, Nathoe HM, Doevendans PA, Klöpping C. Beta-blocker therapy in unstable severe heart failure, evidence or experience? Netherlands Heart Journal [Internet]. 2013 Jan [cited 2020 Dec 28];21(1):3-5. Available from: /pmc/articles/ PMC3528855/?report=abstract

4. Jondeau G, Neuder Y, Eicher JC, Jourdain P, Fauveau E, Galinier M, et al. B-CONVINCED: Beta-blocker CONtinuation Vs. INterruption in patients with Congestive heart failure hospitalizED for a decompensation episode. European Heart Journal [Internet]. 2009 [cited 2020 Dec 28];30(18):2186-92. Available from: https://pubmed. ncbi.nlm.nih.gov/19717851/

5. Böhm M, Link A, Cai D, Nieminen MS, Filippatos GS, Salem R, et al. Beneficial association of $\beta$-blocker therapy on recovery from severe acute heart failure treatment: Data from the Survival of Patients with Acute Heart Failure in Need of Intravenous Inotropic Support trial. In: Critical Care Medicine [Internet]. Lippincott Williams and Wilkins; 2011 [cited 2020 Dec 28]. p. 940-4. Available from: https://pubmed. ncbi.nlm.nih.gov/21283007/

6. Constantinescu AA, Caliskan K, Manintveld OC, van Domburg $R$, Jewbali L, Balk AHMM. Weaning from inotropic support and concomitant beta-blocker therapy in severely ill heart failure patients: take the time in order to improve prognosis. European Journal of
Heart Failure [Internet]. 2014 Apr [cited 2020 Dec 28];16(4):435-43. Available from: http://doi.wiley.com/10.1002/ejhf.39

7. Lee, P.H., Park, GM., Han, S. et al. Beta-blockers provide a differential survival benefit in patients with coronary artery disease undergoing contemporary post-percutaneous coronary intervention management. Sci Rep 10, 22121 (2020). https://doi.org/10.1038/ s41598-020-79214-0

8. Lowes BD, Simon MA, Tsvetkova TO, Bristow MR. Inotropes in the beta-blocker era. Clinical Cardiology [Internet]. 2000 Mar 1 [cited 2020 Dec 28];23(S3):III11-6. Available from: http://doi.wiley.com/10.1002/ clc. 4960231504

9. Jaiswal A, Nguyen VQ, Carry B, Le Jemtel TH. Combination therapy with beta blocker and inotrope in decompensated heart failure: A clinical observation. Heart Res Open J. 2017; 4(1): 18-22. doi: 10.17140/HROJ-4-136

10. Ponikowski P, Voors AA, Anker SD, Bueno H, Cleland JGF, Coats AJS, et al. 2016 ESC Guidelines for the diagnosis and treatment of acute and chronic heart failure [Internet]. Vol. 37, European Heart Journal. Oxford University Press; 2016 [cited 2020 Dec 28]. p. 2129-2200m. Available from: https://academic.oup.com/eurheartj/ article/37/27/2129/1748921

11. Ashkar H, Makaryus AN. Dobutamine. [Updated 2020 Aug 22]. In: StatPearls [Internet]. Treasure Island (FL): StatPearls Publishing; 2021 Jan-. Available from: https://www.ncbi.nlm.nih.gov/books/ NBK470431/

12. Fowler MB, Laser JA, Hopkins GL, Minobe W, Bristow MR. Assessment of the beta-adrenergic receptor pathway in the intact failing human heart: progressive receptor down-regulation and subsensitivity to agonist response. Circulation [Internet]. $1986 \mathrm{Dec}$ [cited 2020 Dec 31];74(6):1290-302. Available from: https://www. ahajournals.org/doi/10.1161/01.CIR.74.6.1290

13. Bollano $E$, Täng MS, Hjalmarson $\AA$, Waagstein F, Andersson B. Different responses to dobutamine in the presence of carvedilol or metoprolol in patients with chronic heart failure. Heart [Internet]. 2003 Jun 1 [cited 2020 Dec 30];89(6):621-4. Available from: /pmc/ articles/PMC1767680/?report=abstract

14. Metra M, Nodari S, D'Aloia A, Muneretto C, Robertson AD, Bristow $\mathrm{MR}$, et al. Beta-blocker therapy influences the hemodynamic response to inotropic agents in patients with heart failure: $A$ randomized comparison of dobutamine and enoximone before and after chronic treatment with metoprolol or carvedilol. Journal of the American College of Cardiology [Internet]. 2002 Oct 2 [cited 2020 Dec 30];40(7):1248-58. Available from: https://pubmed.ncbi.nlm.nih. gov/12383572/

15. Niriayo, Y.L., Asgedom, S.W., Demoz, G.T. et al. Treatment optimization of beta-blockers in chronic heart failure therapy. Sci Rep 10, 15903 (2020). https://doi.org/10.1038/s41598-020-72836-4

16. Hashim, T., Sanam, K., Revilla-Martinez, M., Morgan, C., Tallaj, J.A., Pamboukian, S., Loyaga-Rendon, R., George, J., \& Acharya, D. (2015) Clinical Characteristics and Outcomes of Intravenous Inotropic Therapy in Advanced Heart Failure. Circulation: Heart Failure, 8, 880886.

17. Colucci WS, Wright RF, Braunwald E. New Positive Inotropic Agents in the Treatment of Congestive Heart Failure. New England Journal of Medicine [Internet]. 1986 Jan 30 [cited 2020 Dec 31];314(5):2909. Available from: http://www.nejm.org/doi/abs/10.1056/ NEJM198601303140506

18. Gilbert EM, Abraham WT, Olsen S, Hattler B, White M, Mealy P, et al. Comparative hemodynamic, left ventricular functional, and antiadrenergic effects of chronic treatment with metoprolol versus carvedilol in the failing heart. Circulation [Internet]. 1996 [cited 2020 Dec 30];94(11):2817-25. Available from: https://pubmed.ncbi.nlm.nih. gov/8941107/

19. Metra M, Nodari S, D'Aloia A, Muneretto C, Robertson AD, Bristow $\mathrm{MR}$, et al. Beta-blocker therapy influences the hemodynamic response to inotropic agents in patients with heart failure: A randomized comparison of dobutamine and enoximone before and after chronic treatment with metoprolol or carvedilol. Journal of the American College of Cardiology. 2002 Oct 2;40(7):1248-58. 
20. Gattis WA, O'Connor CM, Gallup DS, Hasselblad V, Gheorghiade M. Predischarge initiation of carvedilol in patients hospitalized for decompensated heart failure: Results of the initiation management predischarge: Process for assessment of carvedilol therapy in heart failure (IMPACT-HF) trial. Journal of the American College of Cardiology [Internet]. 2004 May 5 [cited 2020 Dec 30];43(9):1534-41. Available from: https://pubmed.ncbi.nlm.nih.gov/15120808/

21. Cleland JGF, McGowan J. Levosimendan: A new era for inodilator therapy for heart failure? [Internet]. Vol. 17, Current Opinion in Cardiology. Curr Opin Cardiol; 2002 [cited 2020 Dec 14]. p. 257-65. Available from: https://pubmed.ncbi.nlm.nih.gov/12015475/

22. Lowes BD, Tsvetkova T, Eichhorn EJ, Gilbert EM, Bristow MR. Milrinone versus dobutamine in heart failure subjects treated chronically with carvedilol. International Journal of Cardiology. $2001 ; 81(2-3): 141-9$.

23. Morelli A, Ertmer C, Westphal M, Rehberg S, KampmeierT, Ligges S, et al. Effect of heart rate control with esmolol on hemodynamic and clinical outcomes in patients with septic shock: A randomized clinical trial. JAMA - Journal of the American Medical Association [Internet]. 2013 Oct 23 [cited 2020 Dec 10];310(16):1683-91. Available from: https://jamanetwork.com/

24. Felker GM, Benza RL, Chandler AB, Leimberger JD, Cuffe MS, Califf RM, et al. Heart failure etiology and response to milrinone in decompensated heart failure: Results from the OPTIME-CHF study. Journal of the American College of Cardiology [Internet]. 2003 Mar 19 [cited 2021 Jan 5];41(6):997-1003. Available from: https://pubmed. ncbi.nlm.nih.gov/12651048/

25. Sorsa T, Pollesello P, Rosevear PR, Drakenberg T, Kilpeläinen I. Stereoselective binding of levosimendan to cardiac troponin $C$ causes Ca2+-sensitization. European Journal of Pharmacology [Internet]. 2004 Feb 13 [cited 2021 Jan 7];486(1):1-8. Available from: https:// pubmed.ncbi.nlm.nih.gov/14751401/

26. Pataricza J, Krassói I, Höhn J, Kun A, Papp JG. Functional role of potassium channels in the vasodilating mechanism of levosimendan in porcine isolated coronary artery. Cardiovascular Drugs and Therapy [Internet]. 2003 [cited 2021 Jan 7];17(2):115-21. Available from: https://pubmed.ncbi.nlm.nih.gov/12975592/

27. Szilágyi S, Pollesello P, Levijoki J, Kaheinen P, Haikala H, Édes I, et al. The effects of levosimendan and OR-1896 on isolated hearts, myocyte-sized preparations and phosphodiesterase enzymes of the guinea pig. European Journal of Pharmacology [Internet]. 2004 Feb 13 [cited 2021 Jan 7];486(1):67-74. Available from: https://pubmed. ncbi.nlm.nih.gov/14751410/

28. Follath F, Cleland JGF, Just H, Papp JGY, Scholz H, Peuhkurinen K, et al. Efficacy and safety of intravenous levosimendan compared with dobutamine in severe low-output heart failure (the LIDO study): A randomised double-blind trial. Lancet [Internet]. 2002 Jul 20 [cited 2020 Oct 15];360(9328):196-202. Available from: https://pubmed. ncbi.nlm.nih.gov/12133653/

29. Mebazaa A, Nieminen MS, Filippatos GS, Cleland JG, Salon JE, Thakkar R, et al. Levosimendan vs. dobutamine: Outcomes for acute heart failure patients on $\beta$-blockers in Survive. European Journal of Heart Failure [Internet]. 2009 Mar [cited 2021 Jan 14];11(3):304-11. Available from: https://pubmed.ncbi.nlm.nih.gov/19158152/

30. Bergh $\mathrm{CH}$, Andersson B, Dahlström U, Forfang K, Kivikko M, Sarapohja $\mathrm{T}$, et al. Intravenous levosimendan vs. dobutamine in acute decompensated heart failure patients on beta-blockers.
European Journal of Heart Failure [Internet]. 2010 Apr [cited 2021 Jan 14];12(4):404-10. Available from: https://pubmed.ncbi.nlm.nih. gov/20335355/

31. Rudiger A, Singer M. Mechanisms of sepsis-induced cardiac dysfunction [Internet]. Vol. 35, Critical Care Medicine. Lippincott Williams and Wilkins; 2007 [cited 2021 Jan 14]. p. 1599-608. Available from: https://pubmed.ncbi.nlm.nih.gov/17452940/

32. Dünser MW, Hasibeder WR. Sympathetic overstimulation during critical illness: Adverse effects of adrenergic stress [Internet]. Vol. 24, Journal of Intensive Care Medicine. J Intensive Care Med; 2009 [cited 2021 Jan 14]. p. 293-316. Available from: https://pubmed.ncbi. nlm.nih.gov/19703817/

33. Sanfilippo F, Santonocito C, Morelli A, Foex P. Beta-blocker use in severe sepsis and septic shock: A systematic review. Vol. 31, Current Medical Research and Opinion. Taylor and Francis Ltd; 2015. p. 181725.

34. Fuchs C, Wauschkuhn S, Scheer C, Vollmer M, Meissner K, Kuhn SO, et al. Continuing chronic beta-blockade in the acute phase of severe sepsis and septic shock is associated with decreased mortality rates up to 90 days. British Journal of Anaesthesia [Internet]. 2017 Oct 1 [cited 2021 Jan 14];119(4):616-25. Available from: http://bjanaesthesia. org/article/S000709121753799X/fulltext

35. Rhodes A, Evans LE, Alhazzani W, Levy MM, Antonelli M, Ferrer R, et al. Surviving Sepsis Campaign. Critical Care Medicine [Internet]. 2017 Mar 1 [cited 2020 Dec 10];45(3):486-552. Available from: http:// journals.Iww.com/00003246-201703000-00015

36. Rivers E, Nguyen B, Havstad S, Ressler J, Muzzin A, Knoblich B, et al. Early Goal-Directed Therapy in the Treatment of Severe Sepsis and Septic Shock. New England Journal of Medicine [Internet]. 2001 Nov 8 [cited 2020 Dec 10];345(19):1368-77. Available from: https:// pubmed.ncbi.nlm.nih.gov/11794169/

37. Fuchs C, Wauschkuhn S, Scheer C, Vollmer M, Meissner K, Kuhn SO, et al. Continuing chronic beta-blockade in the acute phase of severe sepsis and septic shock is associated with decreased mortality rates up to 90 days. British Journal of Anaesthesia [Internet]. 2017 Oct 1 [cited 2020 Dec 10];119(4):616-25. Available from: http:// bjanaesthesia.org/article/S000709121753799X/fulltext

38. Zhong J, Hwang TC, Adams HR, Rubin LJ. Reduced L-type calcium current in ventricular myocytes from endotoxemic guinea pigs. American Journal of Physiology - Heart and Circulatory Physiology [Internet]. 1997 [cited 2021 Jan 14];273(5 42-5). Available from: https://pubmed.ncbi.nlm.nih.gov/9374768/

39. Meng JB, Hu MH, Lai ZZ, Ji CL, Xu XJ, Zhang G, et al. Levosimendan versus dobutamine in myocardial injury patients with septic shock: A randomized controlled trial. Medical Science Monitor [Internet]. 2016 May 3 [cited 2021 Jan 14];22:1486-96. Available from: https:// pubmed.ncbi.nlm.nih.gov/27138236/

40. Zangrillo A, Putzu A, Monaco F, Oriani A, Frau G, de Luca M, et al. Levosimendan reduces mortality in patients with severe sepsis and septic shock: A meta-analysis of randomized trials. Journal of Critical Care [Internet]. 2015 Oct 1 [cited 2021 Jan 14];30(5):908-13. Available from: https://pubmed.ncbi.nlm.nih.gov/26093802/

41. Morelli A, de Castro S, Teboul JL, Singer M, Rocco M, Conti G, et al. Effects of levosimendan on systemic and regional hemodynamics in septic myocardial depression. Intensive Care Medicine [Internet]. 2005 May [cited 2021 Jan 14];31(5):638-44. Available from: https:// pubmed.ncbi.nlm.nih.gov/15812624/ 


\section{GRAPHICAL ABSTRACT}

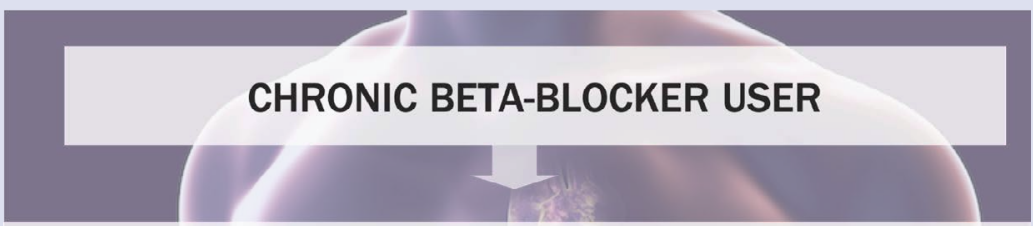

ACUTE DECOMPENSATED HEART FAILURE

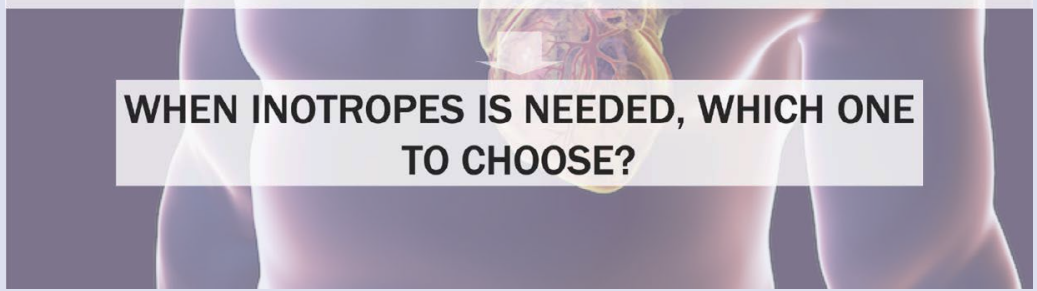

\section{ABOUT AUTHORS}

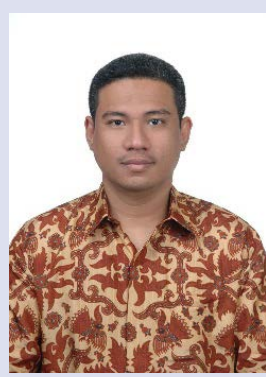

\section{Mochamad Yusuf Alsagaff, MD}

Mochamad Yusuf Alsagaff work as an interventional cardiologist in the Department of Cardiology and Vascular Medicine Soetomo General Hospital and Faculty of Medicine, University of Airlangga. Previously, He led the Acute Cardiac Care Division Cardiology and Vascular Medicine Department in Soetomo General Hospital. His research interests include complex interventional cardiology and acute cardiovascular care.

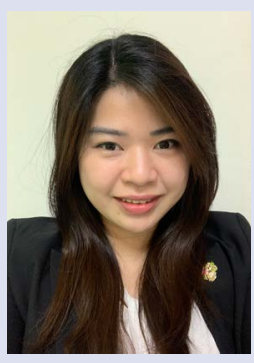

\section{Melly Susanti, MD}

Melly Susanti is a cardiology resident in the Department of Cardiology and Vascular Medicine Soetomo General Hospital and Faculty of Medicine, University of Airlangga. Her research interests are genetic polymorphism of cardiovascular risk and clinical cardiology, endothelial progenitor stem cells.

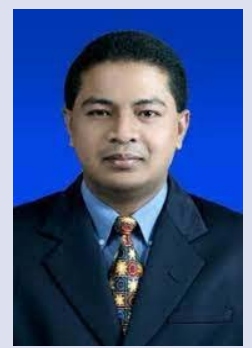

\section{Mochammad Thaha, MD}

Mochammad Thaha work as an Nephrologist in the Department of Internal Medicine Soetomo General Hospital and Faculty of Medicine, University of Airlangga. His research interests include novel biomarkers of kidney damage and reduced kidney function, oxidative stress research in chronic kidney disease. 


\section{Christian Jonatan, MD}

Christian Jonatan is an Internal Medicine Resident in the Department of Internal Medicine Soetomo General Hospital and Faculty of Medicine, University of Airlangga. His research interests are interplay of cardiovascular and renal disease, metabolic and nutritional aspects of patients with kidney disease.

Cite this article: Alsagaff MY, Susanti M, Thaha M, Jonatan C. Inotropes in Chronic Beta-Blocker Therapy. Pharmacog J. 2021;13(3): 828-34. 